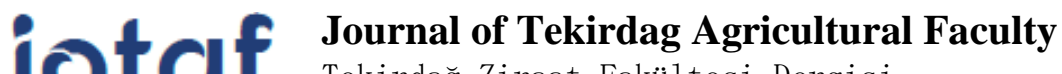 \\ Tekirdağ Ziraat Fakültesi Dergisi
}

\section{Elma Kök Uru Hastalığı Etmeni Rhizobium radiobacter’e Karşı Epifit ve Endofit Bakteri İzolatlarının Antagonistik Potansiyellerinin Belirlenmesi}

\author{
Determination of Antagonistic Potential of Epiphytic and Endophytic Bacterial İsolates \\ Against Apple Crown Gal Disease Agent Rhizobium radiobacter
}

Öz

\section{Adem BOZKURT ${ }^{1}$, Soner SOYLU ${ }^{1 *}$}

Rhizobium radiobacter (=Agrobacterium tumefaciens) tarafından neden olunan kök uru (Taç gal) hastalığı dünya genelinde yaygın olarak yumuşak ve sert çekirdekli meyve ağaçlarının yanı sıra, bağ, sebze ve süs bitkilerinin en önemli hastalıklarından biridir. Hastalık özellikle elma dahil birçok meyve fidanlıklarında ve genç meyve bahçelerde urlu bitkilerde gelişme geriliği sonucu ürün kaybı şeklinde ortaya çıkan önemli düzeylerde ekonomik kayıplara neden olur. Hastalığın kontrolünde fidanların köklerinin dikim öncesi çeşitli kimyasallara daldırılması, toprak fumigasyonu, toprak solarizasyonu ve biyolojik mücadele yöntemleri kullanılmaktadır. Bu çalışmada elma köklerinden izole edilen epifit ve endofit bakterilerinin kök ur hastalığı etmenine karşı antagonistik etkinliği belirlenmiştir. Çalışmada elma ağaçlarının kök ve kök boğazı bölgelerinden 85 aday epifitik ve endofitik bakteri izolatı elde edilmiştir. Aday antagonist bakteri izolatların hastalık etmeni $R$. radiobacter'i baskılama yeteneği öncelikle in vitro ikili kültür testi ile belirlenmiştir. İkili kültür testlerinden elde edilen sonuçlara göre Pseudomonas, Pantoea, Serratia and Bacillus cinslerine dahil farklı türlere ait 12 izolat, besi ortamı üzerinde patojene karşı ortalama 5.0-27.3 mm çapında arasında değişen engelleme zonları oluşturmuştur. Patojen gelişiminin engellenmesi üzerine farklı düzeylerde antagonistik etkinlik gösteren Pseudomonas putida'nın 3 izolatı (1-4en, 1-12en, 1-13en) havuç dilimi üzerinde yarı in vivo etkinlik çalışmaları için seçilmiştir. Pseudomonas putida 1-4en izolatı diğer izolatlara kıyasla havuç dilimi üzerinde ur oluşumunu önemli düzeyde baskılamıştır. Bu çalışmadan elde edilen sonuçlar Pseudomonas putida izolatlarının Rhizobium radiobacter'in neden olduğu kök boğazı ur hastalığına karşı biyolojik mücadele ajanı olarak kullanılabilecek bir potansiyele sahip olduğunu göstermektedir.

Anahtar kelimeler: Biyolojik mücadele, Elma, Rhizobium radiobacter, Kök ur hastalığı, Antagonist bakteri

\begin{abstract}
Crown gal disease, caused by Rhizobium radiobacter (formerly known as Agrobacterium tumefaciens), is one of the most important bacterial plant disease of stone fruits, pome fruits, grape vine, vegetable and ornamental plants distributed worldwide. Disease causes considerable damage in nursery and young orchards of variety of plants including apple where grower may suffer serious economic losses as galled plants show growth reduction and yield. Different control measures have been used against crown gall as a dipping of rooted plants into chemicals, soil fumigation, soil solarization and biological control. The aim of this study was to determine biocontrol efficacies of epiphytic and endophytic bacteria, obtained from apple roots and crowns, against crown gall disease agent. Eighty five putative epiphytic and endophytic antagonist bacterial isolates were obtained from the apple rhizosphere, roots and crown. By using dual culture test, putative antagonist bacterial isolates were

\footnotetext{
${ }^{1 * S o r u m l u ~ Y a z a r / C o r r e s p o n d i n g ~ A u t h o r: ~ S o n e r ~ S o y l u, ~ H a t a y ~ M u s t a f a ~ K e m a l ~ U ̈ n i v e r s i t e s i, ~ Z i r a a t ~ F a k u ̈ l t e s i, ~ B i t k i ~ K o r u m a ~ B o ̈ l u ̈ m u ̈, ~ A n t a k y a / H A T A Y . ~ E-m a i l: ~}$ soylu@mku.edu.tr, OrcID: 0000-0003-1002-8958

${ }^{1}$ Adem Bozkurt, Hatay Mustafa Kemal Üniversitesi, Ziraat Fakültesi, Bitki Koruma Bölümü, Antakya/HATAY. E-mail: iabozkurt@mku.edu.tr, OrcID: 00000002-4826-0317

Atıf/Citation: Bozkurt, İ.A., Soylu, S. Elma kök uru hastalığı etmeni Rhizobium radiobacter'e karşı epifit ve endofit bakteri izolatlarının antagonistik potansiyellerinin belirlenmesi. Tekirdă̆ Ziraat Fakültesi Dergisi, 16(3), CBu çalışma Tekirdağ Namık Kemal Üniversitesi tarafından Creative Commons Lisansı (https://creativecommons.org/licenses/by-nc/4.0/) kapsamında yayınlanmıştır. Tekirdağ 2019
} 
screened for their ability to suppress disease agent $R$. radiobacter in vitro conditions. According to the results obtained from the preliminary dual culture test, 12 isolates, belonging to different bacterial species of Pseudomonas, Pantoea, Serratia and Bacillus genus were found to cause clear inhibition zones of 5.0-27.3 mm diameter. Among the tested antagonist isolates, three different bacterial isolates of Pseudomonas putida 1-4en, 112en and 1-13en were then chosen for semi in vivo studies which were conducted on carrot slice assay. Among these isolates, the most efficient bacterial isolate 1-14en significantly suppressed gall formation on carrot slices. Results of this study revealed that antagonist bacterial isolates of Pseudomonas putida has potential as biocontrol agent for crown gall disease caused by Rhizobium radiobacter

Keywords: Biological control, apple, Rhizobium radiobacter, crown gall, Antagonist Bacteria 
Crown gal disease, caused by Rhizobium radiobacter (formerly known as Agrobacterium tumefaciens), is one of the most important and distributed bacterial disease of pome and stone fruits trees worldwide. Disease is responsible for nursery and field losses among a large variety of plants including apple. Although several control strategies are used for management of crown gall disease including chemicals, pre-plant application of soil sterilant, solarisation and soil amendments, its effective control is still very difficult owing to the lack of effective chemicals. Bacterial microbiomes are numerically the most abundant organisms in soil, nearby roots and inside the healthy plant tissues, and majority of them have been reported to possess great potential for the biological control of soil-borne and other plant diseases. The aim of the present study was to explore the potential of putative endophytic and epiphytic bacterial microbioms for their efficacy to control gall formation in vitro and semi in vivo conditions.

In order to isolate and screen biocontrol potentials of antagonistic bacteria against disease agent, major apple orchards were surveyed and samples were taken from root regions of the healthy apple trees without visible gall symptoms. Following isolation from the surface and inner parts of plant roots, total of 35 endophytic and 50 epiphytic bacteria were isolated on the basis of their morphology. Among all tested putative antagonist bacterial isolates, 1 epiphytic 11 endophytic antagonist bacterial isolates clearly produced variable inhibition zones (5.0$27.3 \mathrm{~mm}$ in diameter). According to fatty acid methyl ester (FAME) profile, 6 isolates were identified as Pseudomonas putida, other five isolates as Pseudomonas fluorescens, Pantoea agglomerans, Sphingomonas yanoikuyae, Bacillus subtilis, Bacillus amyloliquefaciens and Serratia marcescens. Among the tested antagonist bacterial isolates, the most effective three $P$. putida isolates (1-4en, 1-12en and 1-13en) were selected to reveal their antagonistic potentials against bacterial disease agent in semi in vivo conditions. $P$. putida isolates 1-4en, 112en and $1-13$ en were significantly reduced the gall incidence $(75.0 \%, 54.17 \%$ and $20.83 \%$, respectively) on carrot slices.

As far as we know, this is the first study to report that P. putida, P. agglomerans, S. yanoikuyae, $B$. amyloliquefaciens and $S$. marcescens have biocontrol potential against $R$. radiobacter. Bacterial isolates, having antagonistic activities, could be considered as potential sources of environmental friendly bioactive metabolites as well as promising candidates to develop new biological control agent for controlling crown gall disease. Identification of the bioactive metabolites, their ability for root colonization, survival in the rhizosphere and their mechanisms of action of effective biocontrol agents should be further investigated in the field conditions. 
Anavatanı Kafkasya ve Hazar denizi kıyıları olarak bildirilen elma, günümüzde kuzey yarı kürede yer alan hemen bütün ılıman iklime sahip ülkelerde yetiştiriciliği yapılan önemli bir meyvedir (Juniper ve ark., 1998).

Dünyada elma, armut, ayva ve yenidünya meyvelerini kapsayan yumuşak çekirdekli meyve türlerinin üretim alanı 6.410.586 ha olup, toplamda 75.315.918 ton ürün elde edilmektedir. Elma meyvesi 4.933.841 ha'lık alanda 83.139.326 ton'luk üretimiyle yumuşak çekirdekli meyveler içerisinde \%76.98'lik oranı ile birince sırayı alırken, dünya meyve üretimi içerisindeki payı \%9.48\%dir (Anonymous, 2017). Dünyada en fazla elma üretiminin yapıldığı ilk 5 ülke Çin, A.B.D., Türkiye, Polonya, Hindistan ve İran’dır. Ülkemiz 175.357 ha üretim alanda 3.032.164 ton elma üretim ile dünyada elma yetiştiriciliğinde üçüncü sırada yer almaktadır (Anonymous, 2017).

Mineral madde vitamin içeriği bakımından zengin ve önemli bir meyve olan elma üretimi ve verimi fungal, bakteriyel ve viral hastalık etmenleri tarafindan olumsuz yönde etkilenmektedir. Ülkemiz ve dünya genelinde yetiştiriciliği yapılan elma üretimini engelleyen bakteriyel hastalıklardan biriside Rhizobium radiobacter (syn= Agrobacterium tumefaciens) etmeninin neden olduğu kök ve kök boğazı uru hastalığıdır (Lippincott ve ark., 1981). Hastalık etmenin aralarında yumuşak ve sert çekirdekli meyve ağaçları başta olmak üzere, otsu ve odunsu sebze, meyve ve süs bitkilerinin yer aldığ 750 den fazla konukçusu bulunmaktadır (Kado, 2002). Toprak kökenli olan hastalık etmeni, özellikle meyve fidanlarının kök ve kök boğazlarında fidan dikimi, budama, kültürel önlemler, don veya zararlılar tarafindan neden olunan yaralardan bitkiye girmek suretiyle aşırı hücre bölünmeler sonucu kök ve kök boğazında tümör (ur) oluşumuna neden olur. Tümörlerin gözlendiği hücreler büyüdükçe etrafındaki sağlıklı hücrelere basınç uygulayarak bu hücrelerin bozulmasına veya ezilmesine neden olmaktadır. Ksilem dokusunun ezilmesi sonucu bitkilerde üst kısımlara su taşınmasında \%80'e varan oranda azalma meydana gelmektedir (Moore ve ark., 2001; Agrios, 2005). Enfekteli bitkilerde büyüklügüne ve sayısına bağlı olarak oluşturulan urlar sonucu fidanlıklarda fidan gelişimi baskılanırken, yeni tesis edilmiş bahçelerde ciddi verim kayıpları ortaya çıkmaktadır (Kado, 2002). Ülkemizde $R$. radiobacter'in neden olduğu kök boğazı ur hastalığı gül (Aysan ve Şahin, 2003) ve kayısıda (Aysan ve ark., 2003a) rapor edilmiştir. Hastalığın ülkemiz elma ağaçlarında varlığı ilk defa Karaca tarafından saptanmış (Karaca, 1966) olup Akdeniz bölgesindeki elma ağaçlarında varlığı yapılan çalışmalarla da bildirilmiştir (Bozkurt ve Soylu, 2011; Yüzbaşığlu, 2014).

Hastalığın mücadelesinde genel olarak hastalıksız fidan kullanımı, tesis edilecek bahçe toprağının hastalık etmeninden ari olması, toprak solarizasyonu, hastalığa karşı dayanıklı anaçların seçilmesi gibi kültürel önlemler önerilmektedir (Anand ve Mysore, 2006; Gupta ve Kamal, 2006; Horuz ve ark., 2018). Son yıllarda içerisinde aktif madde olarak Agrobacterium rhizogenesis K84 veya K1026 izolatları bulunan biyolojik preparat yaklaşık olarak 30 yıldan buyana hastalıkla mücadelede biyolojik ajan olarak bir çok ülkede kullanılmaktadır (Lopez ve ark., 1989, Farrand, 1990; Moore ve Canfield, 1996; Rhouma ve ark., 2008). Bu izolat uzun yıllar başarılı bir şekilde kullanılmasına rağmen $A$. rhizogenesis K84'te bulunan ve agrocin 84 isimli bakteriosin üretiminin etkilenmesi, dayanıklılıktan sorumsu olan pAg84 geninin konjugal transfer yolu ile patojenik A. tumefaciens izolatlarına aktarılması sonucunda hastalık etmeni agrocine karşı dayanıklı hale gelmiştir (Stockwell ve ark., 1996; Penyalver ve Lopez, 1999). Bu tür olumsuz nedenlerden dolayı hastalığın biyolojik mücadelesinde farklı cinslere ait aday antagonist bakteri(ler)in araştırılması önem arz etmektedir. Genel olarak epifitik olarak kök yüzeyinde veya endofitik olarak hücreler arası boşluklarda veya iletim demetlerinde kolonize olan ve bitki gelişimini teşvik eden bakteriler olarak adlandırılan (Plant Growth Promoting Bacteria, PGPB) bakteriyel izolatlar, antibiyosis, siderofor üretimi, bitkilerde sistemik dayanıklılı̆̆ın uyarılması, hormon oluşturmak suretiyle bitki gelişiminin teşvik gibi farklı mekanizmaları sayesinde birçok bitki hastalığının mücadelesinde yaygın olarak kullanılmaktadır (van Loon ve ark., 1998; Vessey, 2003; Kara ve ark., 2016; Santoyo ve ark., 2016; Sülü ve ark., 2016; Soylu ve ark., 2018).

Ülkemizde son yıllarda artan tüketici talebine karşılık olarak elma dikim alanları hızla artmakta olup, yeni tesis yapılan bahçelerde fungal ve bakteriyel hastalıklar sorun olarak karşılaşılmaktadır. Yapılan bu çalışmada Hatay ilinin en yoğun elma yetiştiriciliğinin yapıldığı Yayladağı ilçesindeki elma ağaçlarında sorun olduğu belirlenen (Bozkurt ve Soylu, 2011) kök boğazı uru hastalığına karşı epifitik ve endofitik antagonist bakterileri ile biyolojik mücadele olanakları in vitro ve yarı in vivo koşullarda araştırılmıştır.

\section{Materyal ve Yöntem}

\section{Çalışmada kullanılan patojen bakteri izolatı}

Çalışmada kullanılan bakteri izolatı Hatay ili, Yayladağı ilçesinde yetiştiriciliği yapılan elma ağaçlarından izole edilmiştir (Bozkurt ve Soylu, 2011). Hastalık etmeni Yağ Asiti Metil Ester (FAME) analizleri sonucu $R$. radiobacter (syn. Agrobacterium tumefaciens) olarak tanılanan ate16 izolatı, havuç dilim testi ve kalanşo bitkilerinde (Kalanchoe blossfeldiana) patojenite testleri sonucu virülensliği belirlenmiştir (Şekil 1). 

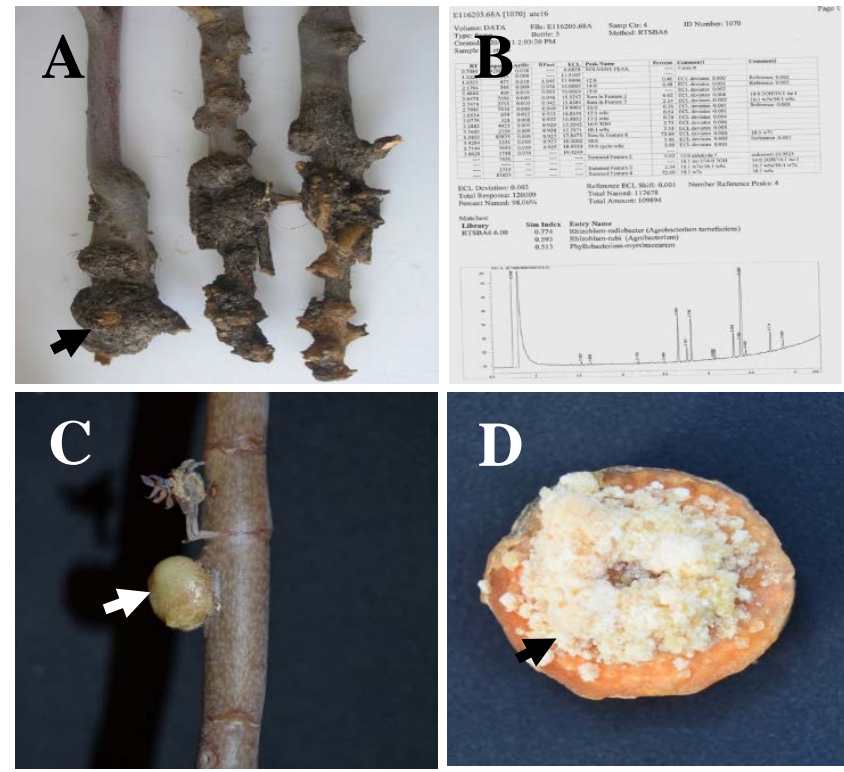

Şekil 1. (A) Elma kök ve kök boğazlarında oluşan tipik hastalık belirtisi olan urlar (ok). (B) Hasta bitkilerdeki urlardan izole edilen bakteri izolatının teşhisinde kullanılan FAME analizi. (C) Kalanşo ve (D) havuç diliminde patojenite testler sonucu oluşan ur belirtileri(ok)

Figure 1. (A) Typical gall symptoms produced on apple crown (arrow). (B) FAME analysis used for identification of bacterial isolates obtained from gall symptoms. Typical gall symtoms (arrows) on Kalanchoe (C) and carrot slice (D) following pathogenicity tests.

\section{Aday epifit ve endofit bakterilerin izolasyonu}

Aday epifit ve endofit antagonist bakteri izolatları hastalığın görüldüğü bahçelerdeki sağlıklı elma ağaçlarının köklerinden izole edilmiştir. Endofit bakteri izolasyonu amacıyla 10-15 cm derinlikteki kök örnekleri ilk aşamada -çeşme suyu ile yıkanmış ve ardından 3 dak. \%70'lik etil alkolde, 2 dak. \%2'lik sodyum hipoklorit solüsyonunda bekletildikten sonra tekrar \%70'lik etil alkole daldırılmış ve 5 kez steril su ile yıkanarak yüzey sterilizasyon yapılmıştır. Sterilizasyonun saflığını kontrol etmek amacıyla son yıkama suyundan $100 \mu 1$ alınarak King B (KB) besi yerine steril bagetle yayılmıș ve petri kapları $24-27^{\circ} \mathrm{C}$ 'de $1-2$ gün inkübasyona bırakılarak bakteriyel gelişmenin olup olmadığı kontrol edilmiştir. İnkübasyon süresi sonunda herhangi bir bakteriyel gelişme görülmeyen örnekler endofit bakterilerin izolasyonunda kullanılmak üzere $+4{ }^{\circ} \mathrm{C}$ bekletilmiştir. Yüzey sterilizasyonu yapılan bitki örnekleri $0.05 \mathrm{mM} \mathrm{MgCl}$ içerisinde ezilmiş ve elde edilen ekstraktan farklı sulandırma serileri hazırlanarak KB besi yerlerine $100 \mu \mathrm{l}$ oranında eklenerek steril baget ile yayılmış ve 24$27^{\circ} \mathrm{C}$ 'de 2 gün boyunca inkübasyona bırakılmıştır.

Epifit bakterilerin izolasyonunda ise kök örnekleri 1-2 $\mathrm{cm}$ boyunda kesildikten sonra dezenfeksiyon amaçlı herhangi bir işlem uygulanmaksızın doğrudan steril $0.05 \mathrm{mM} \mathrm{MgCl} 2$ tampon çözeltisi içine konulmuş ve 30 dak. $200 \mathrm{rpm}$ ortibal çalkalayıcı içerisinde çalkalamaya bırakılmıştır. Süre sonunda süspansiyondan farklı sulandırma serileri hazırlanarak KB besi yerlerine $100 \mu 1$ oranında eklenerek steril baget ile yayılmış ve $24-27^{\circ} \mathrm{C}^{\prime}$ de 2 gün boyunca inkübasyona bırakılmıştır.

İnkübasyon süresi sonunda gelișen farklı morfolojik görünüşlü epifit ve endofit bakteriler her örneği temsil edecek şekilde tek koloniden seçilmiş, çalışmalarda kullanılmak üzere KB besi yeri içeren petri kabında $(6 \mathrm{~cm})$ veya eğik agarda $+4^{\circ} \mathrm{C}$ de kısa süreli veya $\% 40$ steril Gliserol içeren Cryo Eppendorf tüpler içerisinde $-80^{\circ} \mathrm{C}$ 'de saklanmıştır.

\section{Aday antagonist bakteriler ile tütünde aşırı duyarlılık testi (HR= Hypersensitive Reaction)}

Elma köklerinden izole edilen ve patojen bakteriye karşı etkinliği belirlenen aday epifit ve endofit bakteri izolatlarının bitki patojeni olup olmadıklarının belirlenmesi amacı ile saflaştırılan izolatlarla tütünde aşırı duyarlılık testi (HR) yapılmıştır. HR testinde 2 günlük bakteri kültürleri $10^{8}$ hücre/ml (OD=0.13) yoğunlukta 
süspanse edilerek tütün yapraklarına enjekte edilmiştir. Negatif kontrol olarak yapraklara steril saf su inokule edilmiş, pozitif kontrol olarak Bitki Sağlığı Kliniği Kültür Koleksiyon Merkezinden sağlanan bitki patojeni Pseudomonas syringae pv. phaseolicola Psp22 nolu izolat kullanılmıştır. İnokulasyondan 24-48 saat sonra inokule edilen alanlarda oluşan nekrotik görünüm hastalık etmeni pozitif olarak kabul edilmiştir (Lelliot ve Stead, 1987).

\section{Aday antagonist bakteriler ile yumuşak çürüklük testi}

Aday antagonist bakteri izolatların patates dilimi üzerinde yumuşak çürüklük testine tabi tutulmuştur (Lelliot ve Stead, 1987). Yüzey sterilizasyonu yapılmış patates yumrularından aseptik olarak kesilen $2 \mathrm{~cm}$ kalınlığındaki dilimler \%3'lük NaOCl'de 1 dakika bekletilerek dezenfekte edilmiştir. Patates dilimleri daha sonra steril ıslak filtre kâğıdı içeren steril petriler içine yerleştirilmiştir. Hazırlanmış olan patates dilimleri üzerine antagonist bakteri izolatları açılan küçük yaralanmış doku içerisine bulaştırılmıştır. Bulaştırılmış dilimlerin yer aldığı petriler $26{ }^{\circ} \mathrm{C} 2$ gün inkübasyona bırakılmış, daha sonra inokulasyon noktasında çürümelerin varlığ 1 yönünden değerlendirme yapılmıştır (Lelliot ve Stead, 1987). Referans izolat olarak Bitki Sağlığı Kliniği Kültür Koleksiyon Merkezinden sağlanan Pectobacterium caratovorum subsp. caratovorum Ecc8 izolatı kullanılmıştır.

\section{Anatgonist bakterilerin in vitro biyokontrol etkinliklerinin belirlenmesi}

İzolasyonlar sonucu elde edilen aday antagonist bakteri izolatlarının in vitro biyokontrol etkinlikleri KB besi yerinde ikili karşılaştırma (agar difüsyon) testi ile belirlenmiştir (Şekil 2). Antagonistik etkinliği belirlenecek aday epifit ve endofit izolatlarının 24 saatlik kültüründen KB besiyeri içeren petrilere $(9 \mathrm{~cm})$ birbirinden eşit uzaklıkta olmak üzere 3 noktaya ekim yapılmış ve $24 \pm 2^{\circ} \mathrm{C}$ 'de 48 saat inkübasyona bırakılmıştır. $\mathrm{KB}$ besi yerinde gelişen antagonist bakteri izolatları üzerine 24 saatlik patojen süspansiyonu $\left(10^{8}\right.$ hücre/ml $)$ pülverize edilmiştir (Aysan ve ark., 2003b). Kontrol olarak antagonist bakteri yerine bitki patojeni $P$. syringae pv. phaseolicola Psp22 nolu izolat kullanılmıştır. İkili kültürlerin bulunduğu petriler $24 \pm 2^{\circ} \mathrm{C}$ 'de 48 saat inkübasyona bırakılmış ve 48 saat sonunda besiyerinde patojen gelişiminin engellenmesi sonucu oluşan engelleme zonları ile antagonist bakteri izolatlarının koloni çapları ölçülerek indeks değerleri belirlenmiştir (Ullah ve ark, 2017). Her bir bakteri izolatı için 3 petri kullanılmış ve deneme 2 kez yinelenmiştir.

\section{Antagonist bakterilerin yarı in vivo biyokontrol etkinliklerinin belirlenmesi}

In vitro biyokontrol etkinliklerinin belirlendiği çalışmalarda farklı düzeylerde etkili bulunan izolatların yarı in vivo biyokontrol etkinlikleri tarafımızca geliştirilen havuç dilimi testi ile belirlenmiştir. $\mathrm{Bu}$ yöntemde \%70'lik etil alkol ile yüzey sterilizasyonu yapılan kalın havuç meyveleri steril bir bıçak ile $2 \mathrm{~cm}$ kalınlığında dilimlenerek içerisinde steril saf su ile nemlendirilmiş steril kurutma kağıtları bulunan $15 \mathrm{~cm}$ çapındaki steril cam petrilere yerleştirilmiştir. Havuç dilimlerinin üzerine in vitro testlerde değişen oranlarda antagonistik etkinlik gösteren bakteri izolatlarından $50 \mu \mathrm{l}\left(10^{8}\right.$ hücre $\left./ \mathrm{ml}\right)$ inokule edilmiştir. İnokulasyondan 2 saat sonra kök bakterisi inokule edilen dilimlerin üzerine patojen bakteri inokule edilmiş ve $27 \pm 2^{\circ} \mathrm{C}$ 'de 14 gün inkübasyona bırakılmıştır. Kontrol uygulaması olarak antagonist bakteri izolatı yerine $50 \mu$ steril besi yeri konduktan sonra üzerine $R$. radiobacter ate16 izolatı inokule edilmiş (pozitif kontrol) ve yalnız steril su inokule edilmiş (negatif kontrol) dilimler kullanılmıştır.

\section{Antagonist bakteri izolatlarının tanılanması}

Tütünde HR ve patates diliminde yumuşak çürüklük testlerinde negatif sonuç vermiş, biyokontrol etkinlik çalışmalarında farklı düzeylerde patojen gelişimini engelleyen antagonist bakteri izolatlarının tanısı Yağ asitleri metil ester (FAME) özelliklerine göre yapılmıştır (Janse, 1991). Bu yönteme göre, steril bir öze ile test edilecek bakteri kültürlerinin tek kolonilerinden alınarak Tryptic Soy Agar (TSA) besiyerine 4 fazlı çizgi ekim yapılmıştır. Kültürler $27^{\circ} \mathrm{C}$ 'de 14 saat inkübasyon sonrası bakteri kültürlerinin 3. ve 4. fazlarından steril öze ile alınarak teflon kapaklı steril cam tüplere aktarılmıştır. İzolatların yağ asitleri 4 farklı çözeltinin kullanıldığı 4 aşamada yapılmıştır. Hücrelerin parçalanması aşamasında, tüplere transfer edilen bakteri hücrelerinin üzerine çözelti 1'den (45 g NaOH, $150 \mathrm{ml}$ metanol ve $150 \mathrm{ml}$ damitık su) $1 \mathrm{ml}$ eklenmiş ve 5 dak. $100{ }^{\circ} \mathrm{C}$ su banyosunda bekletildikten sonra tekrar su banyosuna konarak ve 25 dakika bekletilmiştir. Süre sonunda tüpler soğuk su banyosunda hızlı bir şekilde soğutulmuştur. Metilleştirme aşamasında, süspansiyonun üzerine çözelti 2'den $2 \mathrm{ml}$ 

(325 ml $6 \mathrm{~N} \mathrm{HCl}$ ve $275 \mathrm{ml}$ metil alkol) eklenmiş ve 5-10 saniye tüp karıştırıcı ile karıştırıldıktan sonra 10 dakika $80^{\circ} \mathrm{C}$ 'lik su banyosunda bekletilmiş ve süre sonunda tüpler hızla soğutulmuştur. Saflaştırma aşamasında, örneklerin üzerine çözelti 3’den $1.25 \mathrm{ml}$ (200 ml heksan ve $200 \mathrm{ml}$ metil tert-butil eter) eklenmiş ve tüplerin ağzı sıkıca kapatıldıktan sonra tüpler dairesel döngü hareketi yapan bir karıştırıcı ile ters-düz edilerek 10 dakika boyunca karıştırılmıştır. İşlem sonunda oluşan iki fazdan alttaki faz pastör pipeti ile uzaklaştırılmış ve üstteki faz bir sonraki aşama için saklanmıştır.

Bazik yıkama aşamasında ise tüplerin üzerine çözelti 4'den (10.8 g NaOH ve $900 \mathrm{ml}$ damıtık su) $3 \mathrm{ml}$ eklenmiş ve tüpler bir önceki aşamada olduğu gibi 5 dakika boyunca ters-düz edilerek çalkalanmıştır. İşlem sonrası oluşan üst fazın 2/3'lük kısmı pastör pipeti ile alınarak gaz kromotografi (GC) tüplerine aktarılmış ve yağ asitleri metil esterler GC (Agilent Technologies 6890N Network GC System) ile izolatların yağ asiti profillerine göre tanıları Sherlock MIS (Microbial Identification System) 4.5, Microbial ID, Inc., Newark, Delaware bilgisayar programı ile yapılmıştır.

\section{İstatistik analiz}

Tüm in vitro denemeleri tesadüf parselleri deneme desenine göre, her bir uygulama için 3 tekerrür olacak şekilde kurulmuştur. Farklı antagonist bakteri uygulamalarının yapıldı̆̆ 1 petrilerdeki engellenme bölgelerinin ölçüm değerleri $(\mathrm{mm})$ ve havuç dilimleri üzerinde kayıt edilen indeks değerleri SPSS istatistik programı (SPSS Statistics 17.0, SPSS Inc., Chicago, IL, USA) kullanılarak tek yönlü ANOVA ile varyans analizi yapılmış ve uygulamalar arasındaki farklılık Duncan’s Multiple Range Testi ile analiz edilmiştir $(\mathrm{P} \leq 0.05)$.

\section{Bulgular}

\section{Aday epifit ve endofit bakterilerin izolasyonu}

Yayladağı ilçesinin yoğun elma yetiştiriciliği yapılan Sebenoba mahallesinde kök ur hastalığının değiş̧ik şiddette gözlendiği bahçelerdeki sağlıklı fidanların kök ve kökboğazı çevresinden yapılan izolasyonlar sonucu KB besi yeri üzerinde örnekleri temsil edecek şekilde 35 adet endofit ve 50 adet epifit olmak üzere toplam 85 bakteri izolatı elde edilmiştir. Elde edilen tüm aday bakteri izolatları tütün yapraklarında HR, patates dilimi üzerinde yumuşak çürüklük testlerine tabi tutulduktan sonra, her iki testte negatif sonuç verdikleri gözlenmiş olup, tüm izolatlar biyokontrol etkinlik çalışmalarında kullanılmıştır.

\section{Aday antagonist bakteri izolatlarının in vitro biyokontrol etkinliklerin belirlenmesi}

In vitro biyokontrol denemelerinde tütünde $\mathrm{HR}$ ve patates çürüklük testlerinde negatif sonuç veren 85 aday antagonist bakteri izolatları arasında 1 epifit ve 11 endofit olmak üzere toplam 12 adet aday antagonist bakteri izolatı, hastalık etmeni $R$. radiobacter'e karşı ikili kültür testlerinde besi yeri üzerinde 5.0 ila $27.3 \mathrm{~mm}$ çapında değişen engelleme zonları (0.3-2.7 indeks değerleri) oluşturmuştur (Çizelge 1, Şekil 2).

Çizelge 1'de verildiği gibi hastalık etmenini besi ortamında engelleme oranlarına göre en başarılı izolatın $27.3 \mathrm{~mm}$ engelleme zonu ile $P$. putida 1-4en nolu endofit bakteri izolatı olup bunu sirası ile $14.3 \mathrm{ve} 14.0 \mathrm{~mm}$ engelleme zonları ile $P$. putida 1-12en ve 1-8en nolu endofitik bakteri izolatları izlemiştir. İzolatlar arasında Pantoea agglomerans 1-10en, Pseudomonas putida 1-13en, 1-20en, Bacillus amyloliquefaciens 5-25en ve Serratia marcescens 5-4ep izolatları her ne kadar engelleme zonu oluşturmuş olsa da istatistiksel olarak kontrol ile aynı grup içinde yer almıştır. 



Şekil 2. Farklı endofit bakterilerin in vitro ikili kültür testlerinde gösterdiği patojeni engelleme zonları (ok).

Figure 2. Typical inhibition zones (arrow) caused by different endophytic bacteria against pathogen in vitro dual culture tests.

Çizelge 1. Sağıkıı bitkilerden elde edilen epifit ve endofit antagonist bakteri izolatlarının $R$. radiobacter'e karşı in vitro antagonistik etkinlikleri

Table 1. In vitro antagonistic efficacies of different epiphytic and endophytic antagonist bacterial isolates obtained from healthy plants against $R$. radiobacter

\begin{tabular}{cccc}
\hline İzolat no & Bakteri Tür İsmi & $\begin{array}{c}\text { Engelleme zon çapi } \\
(\mathbf{m m})^{\mathbf{a}}\end{array}$ & $\begin{array}{c}\text { Engelleme } \\
\text { indeksi }^{\mathbf{b}}\end{array}$ \\
\hline $1-4 \mathrm{en}$ & Pseudomonas putida & $27.3 \mathrm{~h}$ & $2.07 \mathrm{~d}$ \\
\hline $1-8 \mathrm{en}$ & Pseudomonas putida & $14.0 \mathrm{~g}$ & $1.37 \mathrm{c}$ \\
\hline $1-9 \mathrm{en}$ & Pseudomonas fluorescens & $13.0 \mathrm{fg}$ & $1.32 \mathrm{bc}$ \\
\hline $1-10 \mathrm{en}$ & Pantoea agglomerans & $7.0 \mathrm{bc}$ & $1.18 \mathrm{bc}$ \\
\hline $1-12 \mathrm{en}$ & Pseudomonas putida & $14.3 \mathrm{~g}$ & $1.38 \mathrm{c}$ \\
\hline $1-13 \mathrm{en}$ & Pseudomonas putida & $8.0 \mathrm{~cd}$ & $1.22 \mathrm{bc}$ \\
\hline $1-20 \mathrm{en}$ & Pseudomonas putida & $5.0 \mathrm{~b}$ & $1.15 \mathrm{bc}$ \\
\hline $1-21 \mathrm{en}$ & Sphingomonas yanoikuyae & $9.7 \mathrm{de}$ & $1.12 \mathrm{~b}$ \\
\hline 5-3en & Pseudomonas putida & $10.3 \mathrm{e}$ & $1.24 \mathrm{bc}$ \\
\hline 5-22en & Bacillus suptilis & $11.0 \mathrm{ef}$ & $1.32 \mathrm{bc}$ \\
\hline 5-25en & Bacillus amyloliquefaciens & $6.0 \mathrm{bc}$ & $1.21 \mathrm{bc}$ \\
\hline 5-4ep & Serratia marcescens & $6.7 \mathrm{bc}$ & $1.26 \mathrm{bc}$ \\
\hline Kontrol & Pseudomonas syringae pv. phaseolicola & $0.00 \mathrm{a}$ & $0.00 \mathrm{a}$ \\
\hline
\end{tabular}

${ }^{a}$ Aynı sütun içinde yer alan ortalama engelleme zon çapı $(\mathrm{mm})$ değerlerin yanındaki benzer harfler uygulamalar arasındaki farkın istatistiksel olarak önemli olmadığını gösterir (Duncan’s Multiple Range Test, $P \leq 0.05$ ).

${ }^{\mathrm{b}}$ İndeks değeri engelleme zon çapının bakteri izolatlarının koloni çaplarına kıyaslanmak suretiyle belirlenmiştir. Sütun içinde yer alan ortalama indeks değerlerin yanındaki benzer harfler uygulamalar arasındaki farkın istatistiksel olarak önemli olmadığını gösterir (Duncan’s Multiple Range Test, $P \leq 0.05$ ).

Çizelge 1'de görüldüğü gibi ikili kültür testleri sonucu farklı oranda engelleme zonu oluşturan 11 izolat, FAME yöntemi kullanılmak suretiyle yağ asit metil ester profillerine göre tanılanmış olup, tanılama çalışmaları sonucunda patojen gelişimini değişen oranlarda engelleyen 12 farklı antagonist izolattan 6 tanesinin Pseudomonas putida olduğu, diğerlerinin ise 1'er izolat ile Pseudomonas fluorescens, Pantoea agglomerans, Sphingomonas yanoikuyae, Bacillus subtilis, Bacillus amyloliquefaciens ve Serratia marcescens olduğu belirlenmiştir. 


\section{Antagonist bakterilerin yarı in vivo biyokontrol etkinliklerinin belirlenmesi}

Antagonist bakterilerin yarı in vivo biyokontrol etkinliklerinin belirlenmesi havuç dilimleri üzerinde yapılan çalışmalar ile belirlenmiştir. Yarı in vivo biyokontrol etkinlik çalışmalarında, in vitro ikili kültür etkinlik çalışmalarında farklı düzeylerde etkinlik gösteren Pseudomonas putida'nın 3 farklı bölgeden elde edilen izolatı (P. putida 1-4en, 1-12en ve 1-13en izolatları) kullanılmıştır. Antagonist bakterilerin hastalık etmeni üzerindeki biyokontrol etkinlikleri, uygulamalardan 2 hafta sonra pozitif kontrol uygulamasındaki ur oluşumları ile karşılaştırılmak suretiyle ile belirlenmiştir (Çizelge 2, Şekil 3).

Çizelge 2. Epifit ve endofit bakterilerin yarı in vivo koşullarda ur oluşumu üzerine olan antagonistik etkinliği

Table 2. Antagonistic efficacies of epiphytic and endophytic bacterial isolates on gall formation semi in vivo conditions

\begin{tabular}{ccc}
\hline İzolat no & Ur oluşum şiddeti & \%Engelleme \\
\hline$P$. putida 1-4en & $1.20 \mathrm{a}$ & 75.00 \\
\hline P. putida 1-12en & $2.20 \mathrm{~b}$ & 54.17 \\
\hline P. putida 1-13en & $3.80 \mathrm{c}$ & 20.83 \\
\hline R. radiobacter ate6 (Kontrol) & $4.80 \mathrm{~d}$ & -
\end{tabular}

Aynı sütun içinde yer alan ortalama değerlerin yanındaki benzer harfler uygulamalar arasındaki farkın istatistiksel olarak önemli olmadığını gösterir (Duncan’s Multiple Range Test, $P \leq 0.05$ ).
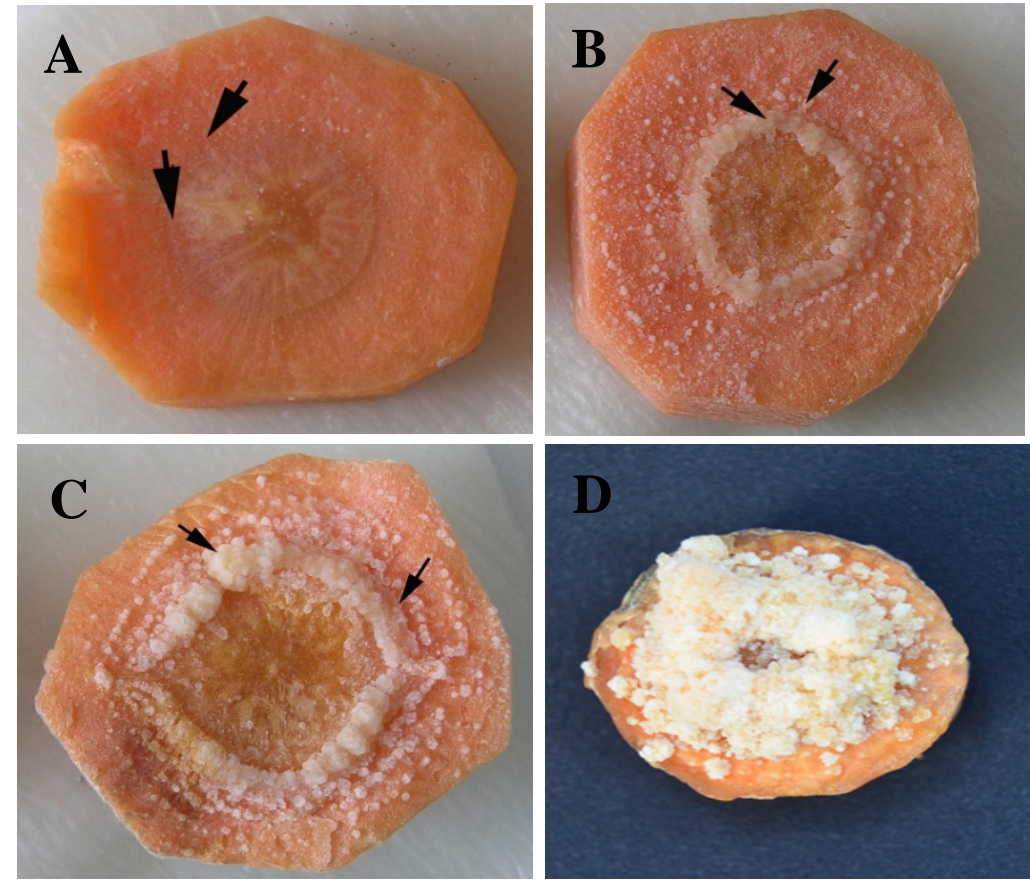

Şekil 3. Farklı endofit bakterilerin havuç dilimleri üzerinde hastalık çıkışı üzerine etkinliği. (A) 1-4en izolatı, (B) 1-12en ve (C) 113en izolatları ile birlikte inokule edilen havuç dilimi üzerinde değişen şiddetlerde ur şeklinde oluşan hastalık belirtileri (ok). (D) Sadece patojenle inokule edilmiş kontrol uygulaması.

Figure 3. Efficacies of different endophytic bacteria on disease suppressions on carrot slices. Occurrence of different level of gall formation on carrot slices following treatment with (A) 1-4en, (B) 1-12en and (C) 1-13en isolates (arrow). (D) Shows typical gall symptom on carrot slice following pathogenicity test (control treatment).

İnokulasyondan sonra yapılan değerlendirmede inokule edilen havuç dilimleri üzerinde in vitro çalışmalarda en etkili izolat olan $P$. putida 1-4en ile inokule edilen yerlerde hastalık etmenin oldukça düşük düzeyde ur 
oluşturduğu gözlenirken (Şekil 3a), diğer izolatlarda artan şiddetlerde ur oluşumları tespit edilmiştir (Şekil 3b-c). Çizelge 2'de görüleceği gibi, test edilen $P$. putida 1-4en, 1-12en ve 1-13en izolatları uygulandıkları havuç dilimleri üzerinde kontrole oranla ur oluşumunu sırasıyla $\% 75, \% 54.17$ ve $\% 20.83$ oranlarında azalttığ belirlenmiştir. Yalnızca patojenle inokule edilmiş havuç dilimi üzerinde oldukça yoğun şiddette ur oluşumu gözlenmiş olup (Şekil 3d), söz konusu 3 izolatta kontrole kıyasla ur çıkışı ve şiddeti üzerinde oldukça önemli düzeyde engelleme göstermiştir (Çizelge 2).

\section{Sonuç}

Bitkilerin endosphere olarak bilinen içsel doku bölgesi birçok faydalı veya zararlı mikroorganizmalara konukçuluk eder. Bu bölgelerde en fazla bildirilen antagonist bakteri türlerinin Pseudomonas, Bacillus, Burkholderia, Stenotrophomonas, Micrococcus, Pantoea ve Microbacterium cinslerine dahil türler olduğu bildirilmiştir (Sturz ve ark., 2000; Rosenblueth ve Martínez-Romero 2006; Romero ve ark., 2014; Bozkurt ve Soylu, 2016; Sülü ve ark., 2016; Kara ve ark., 2016; Soylu ve ark., 2018). Elma dahil oldukça geniş konukçu dizilimine sahip olan kök ur hastalığ 1 etmeni $R$. radiobacter ile biyolojik mücadele konusunda oldukça kısıtlı sayıda çalışma mevcuttur. Hastalıkla biyolojik mücadelede genellikle $R$. radiobacter K84 veya K1026 izolatlarının kullanıldığı çalışmalar (Moore ve Warren, 1979; Penyalver ve ark., 2000) dışında hastalık etmeni ile biyolojik mücadele avirulent Rhizobium vitis, Bacillus subtilis, Pseudomonas fluorescens, Pseudomonas aureofaciens izolatlarının antagonistik etkinlik gösterdiğinin belirlendiği bildirimler bulunmaktadır (Khmel ve ark., 1998; Gupta ve Khosla, 2007; Rhouma ve ark., 2008; Kawaguchi ve ark., 2012). Epifitik ve endofitik PGPB izolatlarının bulundukları yer açısından hangisinin avantajlı veya etkili olduğu hususlarda birçok tartışma bulunmaktadır (Rosenblueth ve Martínez-Romero, 2006). Bununla birlikte doku içinde yaşayan endofit PGPB izolatlarının kök bölgesinde serbest olarak yaşayan, pek çok çevre faktörleri ile etkileşime giren epifit PGPB izolatlarına kıyasla bitkiye daha fazla avantaj sağladığına dair pek çok çalışma bulunmaktadır (Coutinho ve ark., 2015; Santoyo ve ark., 2016).

Çalışmamızda elma kök ur hastalığı etmenine karşı antagonistik etkinliğin araştırıldığı 85 izolat arasında yüksek engelleme etkinliği genellikle endofit karakterli izolatların gösterdiği, epifit bakteri izolatların büyük bir çoğunluğunun ise etkinlik gösteremediği belirlenmiştir. Hastalık etmenine karşı sağlıklı bitkilerden elde edilen Pseudomonas, Bacillus, Pantoae, Sphingomonas ve Serratia spp ait endofit ve epifit bakteri izolatların in vitro ve yarı in vivo biyokontrol etkinliklerin belirlendiği çalışmalarda antagonist izolatlar arasında önemli istatistiksel farklılıkların olduğu, P. putida'nın farklı bölgelerden elde edilen izolatların diğer izolatlara kıyasla genelde yüksek düzeyde antagonistik etkinlik gösterdiği belirlenmiştir. Yapılana önceki çalışmalarda Pseudomonas, Bacillus, Pantoae, Sphingomonas ve Serratia spp ait birçok bakteri izolatının daha çok fungal hastalık etmenlerine karşı antagonistik ve PGPB etkinliğe sahip olduğu ortaya konulmuş olup (Kim ve ark., 1998; Berg ve ark., 2005; Soylu ve ark., 2005; Garcia ve Romeiro 2011; Lopez-Reyes ve ark., 2014; Kara ve ark., 2016; Matilla ve Krell, 2018; Soylu ve ark., 2018), test edilen P. putida, Pantoea agglomerans, Sphingomonas yanoikuyae, Bacillus amyloliquefaciens ve Serratia marcescens izolatlarının $R$. radiobacter etmenine karşı antagonist etkinliği ilk kez bu çalışmada belirlenmiştir. Kheirandish ve Harighi (2015) tarafından yapılan çalışmada patates yumrularının kök bölgelerinden elde edilen 52 bakteri izolatı arasında aralarında Pseudomonas putida Pp17 bulunduğu, Pseudomonas fluorescens Pf11, P. fluorescens Pf16, Paenibacillus sp. Pb28 ve Enterobacter sp. En38 gibi 8 izolatın bakteriyel solgunluk hastalığ etmeni Ralstonia solanacearum in vitro ve in vivo koşullarda engellediğini bildirmiştir. Hidrojen siyanür (HCN), siderofor ve protease P. putida'nın hastalık gelişimini engellemede kullandığı engelleme mekanizmalar olarak belirlenmiştir. Çalışma sonuçları P.putida'nın sahip olduğu antagonistik etkinliğinin yanısıra bitki gelişiminide önemli düzeyde teşvik etmesi nedeniyle hastalıkla mücadelede çok yüksek kullanılma potansiyelinin bulunduğunu bildirilmiştir. Tajalipour ve ark. (2014) kompostlardan elde edilen 120 izolat arasında aralarında $P$. putida, P. reactants, $P$. fluorescens ve Bacillus subtilis türlerine dahil 36 antagonist bakteri izolatının mantar kahverengi leke hastalığı etmeni Pseudomonas tolaasii'ye karşı in vitro ve in vivo koşullarda antagonistik etkinlik gösterdiğini bildirmişlerdir. Antagonist izolatların in vivo hastalık çıkışının \%12.9-60.0 arasında engellediği bildirilmiştir. Söz konusu çalışmada aynı bu çalışmada elde edildiği gibi aynı türe ait izolatlar arasında gerek in vitro gerekse in vivo koşullarda hastalık etmenine karşı değişen oranlarda etkinlikler gösterdiği bildirilmiştir. Gerami ve ark (2013) armut ağaçlarının 3 farklı gelişme döneminden elde ettikleri 20 izolat arasında Pseudomonas fluorescens (E10), Pantoea agglomerans (Abp2), Pseudomonas putida (En) ve Serratia marcescens türlerine dahil 4 antagonist bakteri izolatının ateş yanıklığı hastalığı etmeni Erwinia amylovora'ya karşı in vitro ve in vivo koşullarda antagonistik etkinlik gösterdiğini bildirmişlerdir. Antagonist izolatların in vivo hastalık çıkışının \%23-60 arasında engellediği bildirilmiştir.

Ülkemizde söz konusu hastalık etmeni $R$. radiobacter ile yapılmış biyolojik mücadele çalışması bulunmamaktadır. Küsek ve Çınar (2012) asmada kök ur hastalığı etmeni A. vitis’e karşı epifitik olarak izole 

edilmiş toplam 464 izolat arasında PGPB özellik gösteren Ga7/3-6, Ga10/2-5, Os1/3-1, OsD1/3-1 ve HaD6/3-1 izolatlarının asmada ur oluşumunu \%45-98 oranında azalttı̆̆ını bildirmişlerdir.

Antagonist bakteri izolatlarının in vitro ve in vivo koşullarda göstermiş olduğu patojen gelişimini engellemede kullanılan mekanizmalar üzerine çalışmamız olmasa da, yüksek düzeyde antagonistik etkinlik gösteren Pseudomonas, Bacillus, Serratia, Pantoae spp. ait bakteri izolatların daha önce yapıllmış çalışmalarda farklı hastalık etmenlerinin gelişimini engellemede kullandığı antagonistik mekanizmaların başta protease, chitinase, glucanase gibi litik enzimler olmak üzere, farklı kimyasal yapıda antibiyotikler, fenolikler, siderofor, HCN, amonyak gibi bileşiklerin sorumlu olduğu bildirilmiştir (Hallmann ve ark., 1997; Tabarraei ve ark, 2011; Gupta ve ark., 2015).

Sonuç olarak çalışmada antagonistik aktiviteleri in vitro ve in vivo çalışmalarla ortaya konmuş, tür düzeyinde tanılanmış bakteriyel izolatlar, başta kök ur hastalığına karşı olmak üzere diğer önemli bakteriyel ve fungal hastalıklarla mücadelede gelecek vaat eden biyolojik kontrol ajanı adayları olarak düşünülebilir. Bu izolatların doğrudan kullanılmasının yanı sıra hastalığı engellemede rol oynayan bileşiklerin benzer amaç doğrultusunda kullanılmak üzere potansiyel yeni biyoaktif metabolit kaynakları olarak da değerlendirilmelidir. Burada izole edilen antagonistik bakterilerin biyoaktif metabolitlerini tanımlamak, etkili biyolojik kontrol ajanları olarak etki mekanizmalarını belirlemek, rizosferde kök kolonizasyonu ve hayatta kalma kabiliyetlerinin belirlenmeleri gibi çalışmaların gelecekteki test edilmesi ayrı bir önem arz etmektedir.

\section{Teşekkür}

Bu çalışma Hatay Mustafa Kemal Üniversitesi, Bilimsel Araştırma Projeleri Komisyonunca (MKU BAP-10820) desteklenmiştir. 


\section{Kaynakça/References}

Agrios, G.N. (2005). Plant Pathology. 5th Edition, Elsevier Academic Press, Amsterdam 952 p.

Anand A., Mysore K.S. (2007) Agrobacterium biology and crown gall disease. In: Plant-Associated Bacteria. Gnanamanickam S.S. (Ed.). Springer, Dordrecht. pp. 359-384

Anonymous, (2017). FAOSTAT, Food and Agriculture Organization of The United Nations (FAO). http://www.fao.org.tr (Erişim tarihi: 14.04.2019).

Aysan, Y., Şahin, F. (2003). An outbreak of crown gall disease on rose caused by Agrobacterium tumefaciens in Turkey. Plant Pathology 52: 780 .

Aysan, Y., Şahin, F., Mirik, M., Dönmez, M., F., Tekman, H. (2003a). First report of crown gall of apricot (Prunus armeniaca) caused by Agrobacterium tumefaciens in Turkey. Plant Pathology 52: 793.

Aysan, Y., A. Karatas and O. Cinar, 2003b. Biological control of bacterial stem rot caused by Erwinia chrysanthemi on tomato. Crop Protection 22 (6) 807-811.

Berg, G., Krechel, A., Ditz, M., Sikora, RA., Ulrich, A., Hallmann, J. (2005). Endophytic and ectophytic potato-associated bacterial communities differ in structure and antagonistic function against plant pathogenic fungi. FEMS Microbiology Ecology 51: 215-229.

Bozkurt, İ.A., Soylu, S. (2011). Hatay ili elma bahçelerinde Agrobacterium tumefaciens'in neden olduğu kök boğazı uru hastalığının belirlenmesi. IV. Bitki Koruma Kongresi. Bildiriler, 28-30 Haziran, Kahramanmaraş, s. 315.

Bozkurt, İ.A., Soylu, S., (2016). Determination of effects of Plant Growth Promoting Rhizobacteria (PGPR) on seed germination and shoot growth of parsley (Petroselinum crispum L.). Turkey $6^{\text {th }}$ Plant Protection Congress with International Participation (5-8 September 2016, Konya, TURKEY): 149.

Coutinho, B.G., Licastro, D., Mendonc, Previato, L., Cámara, M., Venturi, V. (2015). Plant-influenced gene expression in the rice endophyte Burkholderia kururiensis M130. Molecular Plant-Microbe Interactions 28: 10-21.

Farrand, S.K. (1990). Agrobacterium radiobacter strain K84: a model control system. In: Ralph R. Baker, Peter E. Dunn (eds) New Directions in Biological Control: Alternatives for Suppressing Agricultural Pests and Diseases, pp. 679-691.

Garcia, F.A.D., Romeiro, R.D. (2011). Biocontrol of bean angular leaf spot by bacterial antagonists. Pesquisa Agropecuaria Brasileira 46: 1603-1608.

Gerami, E., Hassanzadeh, N., Abdollahi, H., Ghasemi, A., Heydari, A. (2013). Evaluation of some bacterial antagonists for biological control of fire blight disease. Journal of Plant Pathology 95: 127-134.

Gupta, A.K., Kamal, B. (2006). Pre-planting application of soil sterilents and herbicides for management of crown gall disease on 'colt' cherry rootstock. Indian Journal of Agricultural Sciences 76: 426-429.

Gupta, A.K., Khosla, K. (2007). Integration of soil solarization and potential native antagonist for the management of crown gall on cherry rootstock colt. Scientia Horticulturae 112: 51-57.

Gupta G., Parihar S.S., Ahirwar N.K., Snehi S.K., Singh V. (2015). Plant growth promoting rhizobacteria (PGPR): Current and future prospects for development of sustainable agriculture. Journal of Microbial and Biochemical Technology 7: 096-102.

Hallmann, J., Quadt-Hallmann, A., Mahaffee, W.F., Kloepper, J.W. (1997). Bacterial endophytes in agricultural crops. Canadian Journal of Microbiology 43: 895-914.

Horuz, S., Çağlar, B.K,. Kusek, M., Aysan, Y. (2018). Crown gall disease susceptibility of some stone fruit rootstocks in Turkey. Tarım Bilimleri Dergisi 24:439-444.

Janse J.D. (1991). Pathovar discrimination within Pseudomonas savastanoi subsp. savastanoi using whole cell fatty acid analysis and pathogenicity as criteria. Systematic and Applied Microbiology 14: 79-84.

Juniper, B.E., Watkins, R. and Harris, S.A. (1998). The origin of the apple. Acta Horticulture 484: 27-34.

Kado, C. I. (2002). Crown gall. http://www.apsnet.org/ edcenter/Pages/phi.aspx (Erişim tarihi: 10.04.2019).

Kara, M., Soylu, E.M., Kurt, S., Soylu, S. (2016). Determination of antagonistic efficiency of endophytic bacteria against gray mold disease agent Botrytis cinerea in vitro conditions. Turkey $6^{\text {th }}$ Plant Protection Congress with International Participation (5-8 September 2016 Konya, TURKEY): p. 156

Karaca, İ. (1966). Sistematik Bitki Hastalıkları (Bakteriyel Hastalıklar) Cilt 1. 210s.

Kawaguchi, A., Kondo, K., Inoue, K. (2012). Biological control of apple crown gall by nonpathogenic Rhizobium vitis strain VAR03-1. Journal of General Plant Pathology 78: 287-293. 

Biological Control 86: 14-19.

Khmel, I.A., Sorokina, T.A., Lemanova, N.B., Lipasova, V.A., Metlitski, O.Z,, Burdeinaya, T.V., Chernin, L.S. (1998). Biological control of crown gall in grapevine and raspberry by two Pseudomonas spp. with a wide spectrum of antagonistic activity. Biocontrol Science and Technology 8: 45-57.

Kim, H., Nishiyama, M, Kunito T, Senoo K, Kawahara K, Murakami K, Oyaizu, H. (1998). High population of Sphingomonas species on plant surface. Journal of Applied Microbiology 85: 731-736.

Küsek, M., Çınar Ö. (2012). Bitki büyümesini teşvik eden kök bakterilerini kullanılarak asma uru hastalığı etmeni Agrobacterium vitis’in biyolojik mücadelesi. Türkiye Biyolojik Mücadele Dergisi 3: 21-36.

Lelliot, R.A., Stead, D.E. (1987). Methods for the diagnosis of bacterial diseases of plants. In: Methods in Plant Pathology, T.F. Preece, (Ed.). Black well Scientific Publications, Oxford. pp, 176-177.

Lippincott, J.A., Lippincott, B.B. and Starr, M.P. ( 1981) The genus Agrobacterium. In: The Prokaryotes. M.P. Starr, H. Stolp, H.G. Trup, A. Balows and H.G. Schegel (Eds.). Springer

- BABag, New York. Pp, 842

López, M.M., Gorris, M.T., Salcedo, C.I., Montojo, A.M., Miró, M. (1989). Evidence of biological control of Agrobacterium tumefaciens strains sensitive and resistant to agrocin 84 by different Agrobacterium radiobacter strains on stone fruit trees. Applied and Environmental Microbiology 55: 741-746.

Lopez-Reyes, J.G., Gilardi, G., Garibaldi, A., Gullino, M.L. (2014). Efficacy of bacterial and fungal biocontrol agents as seed treatments against Fusarium oxysporum f. sp lactucae on lettuce. Journal of Plant Pathology 96: 535-539.

Matilla, M.A., Krell, T. (2018). Plant growth promotion and biocontrol mediated by plant-associated bacteria. In: Plant Microbiome: Stress response, Microorganisms for Sustainability 5, D. Egamberdieva and P. Ahmad (eds.), Springer Nature Singapore Pte Ltd. pp 45-80.

Moore, L,W., Warren, G., (1979). Agrobacterium radiobacter strain 84 and biological control of crown gall. Annual Review of Phytopathology 17:163-179

Moore, L,W., Canfield, M., (1996). Biology of Agrobacterium and management of crown gall disease. In: Principles and Practice of Managing Soilborne Plant Pathogens, R. Hall (Ed.). APS Press, St. Paul, Minnesota. pp, 151-191.

Moore, L.W., Bouzar, H., Burr, T.J. ( 2001) Agrobacterium. In: Plant Pathogenic Bacteria. N.W. Schaad, J.B. Jones and W. Chun (Ed.). APS Press, St. Paul, Minnesota. pp, 17- 34.

Penyalver, R., Lopez, M.M. (1999). Colonization of the rhizosphere by pathogenic Agrobacterium strains and nonpathogenic strains K84 and K1026, used for crown gall biocontrol. Applied and Environmental Microbiology 65: 1936-1940.

Penyalver, R., Vicedo, B., Lopez, M.M. (2000). Use of genetically engineered Agrobacterium strain K1026 for biological control of crown gall. European Journal of Plant Pathology 106: 801-810.

Rhouma, A., Bouri, M., Boubaker, A., Nesme, X. (2008). Potential effect of rhizobacteria in the management of crown gall disease caused by Agrobactertum tumefaciens Biovar 1. Journal of Plant Pathology 90: 517-526.

Romero, F.M., Marina, M., Pieckenstain, F.L. (2014). The communities of tomato (Solanum lycopersicum L.) leaf endophytic bacteria, analyzed by 16S-ribosomal RNA gene pyrosequencing. FEMS Microbiology Letters 351: 187-194.

Rosenbluet, M,. Martinez-Romero, E. (2006). Bacterial endophytes and their interactions with hosts. Molecular Plant-Microbe Interactions 19, 827-837.

Santoyo G., Moreno-Hagelsieb, G, Carmen Orozco-Mosquedac, M, Glick, B.R. (2016). Plant growth-promoting bacterial endophytes. Microbiological Research 183: 92-99

Soylu, S., Soylu, E.M., Kurt, Ş., Ekici, Ö.K. (2005). Antagonistic potentials of rhizosphere-associated bacterial isolates against soil-borne diseases of tomato and pepper caused by Sclerotinia sclerotiorum and Rhizoctonia solani. Pakistan Journal of Biological Sciences 8: 4348.

Soylu, S., Kara, M., Üremiş, İ., Kurt, Ş., Soylu, E.M., Uysal, A., (2018). Determination of plant growth promoting traits of bacterial endophytes isolated and identified from invasive plant water hyacinth Eichhornia crassipes in Orontes river of Turkey. 1. International Mediterranean Symposium (01-03 November 2018, Mersin/Turkey): 349-350

Stockwell, V.O., Kawalek, M.D., Moore, L.W., Loper, J.E. (1996). Transfer of pAgK84 from the biocontrol agent Agrobacterium radiobacter K84 to A. tumefaciens under field conditions. Phytopathology 86: 31-37.

Sturz, A.V., Christie, B.R. Nowak, J. (2000). Bacterial endophytes, potential role in developing sustainable systems of crop production. Critical Reviews in Plant Sciences 19: 1-30.

Sülü, S.M., Bozkurt, İ.A. Soylu, S. (2016). Bitki büyüme düzenleyici ve biyolojik mücadele etmeni olarak bakteriyel endofitler. Mustafa Kemal Üniversitesi Ziraat Fakültesi Dergisi 21: 103-111.

Tabarraei, M., Amini, J., Harighi, B. (2011). Effects of fluorescent Pseudomonads for control of damping-off disease of cantaloupe caused by Phytophthora drechsleri. Australian Journal of Crop Science 5: 1427-1433. 
JOTAF/ Journal of Tekirdag Agricultural Faculty, 2019, 16(3)

Tajalipour, S., Hassanzadeh, N., Jolfaee, H.K., Heydari, A., Ghasemi, A. (2014). Biological control of mushroom brown blotch disease using antagonistic bacteria. Biocontrol Science and Technology 24: 473-484.

Ullah, A., Mushtaq, H., Fahad, S., Shah, A. Chaudhary, H.J. (2017). Plant growth promoting potential of bacterial endophytes in novel association with Olea ferruginea and Withania coagulans. Microbiology 86: 119-127.

Van Loon L.C., Bakker, P.A.H.M., Pieterse, C.M.J., 1998. Systemic resistance induced by rhizosphere bacteria. Annual Review of Phytopathology 36: 483-553.

Vessey, K.J. (2003). Plant growth promoting rhizobacteria as biofertilizers, Plant and Soil 255: 571-586.

Yüzbaşığlu, E.G. (2014). Farklı konukçu bitkilerden izole edilen Agrobacterium tumefaciens izolatlarının fenotipik ve genotipik karakterizasyonu. Doktora Tezi, Çukurova Üniversitesi Fen Bilimleri Enstitüsü, Bitki Koruma Anabilim Dalı, 139 s. 